\title{
The Roles of Personality in the Context of Knowledge Sharing: A Malaysian Perspective
}

\author{
Halimah Abdul Manaf ${ }^{1} \&$ Najib Ahmad Marzuki ${ }^{2}$ \\ ${ }^{1}$ School of Government, College of Law, Government and International Studies, Universiti Utara Malaysia, \\ Kedah, Malaysia \\ ${ }^{2}$ School of Social Development, College of Art and Sciences, Universiti Utara Malaysia, Kedah, Malaysia \\ Correspondence: Halimah Abdul Manaf, College of Law, Government and International Studies, Universiti \\ Utara Malaysia, 06010 Kedah, Malaysia. Tel: 60-1-9323-1684, E-mail: imah@uum.edu.my
}

Received: August 8, 2013 Accepted: October 27, 2013 Online Published: December 31, 2013

doi:10.5539/ass.v10n1p138 URL: http://dx.doi.org/10.5539/ass.v10n1p138

\begin{abstract}
Our era of knowledge today has shown the fact that accomplishments achieved by public agencies receive influence from several inside factors; to name but a few, individual intelligence and personality characteristics. The emphasis on this paper rests on the contributions made by personality and the act of implicit knowledge-sharing to improve individual presentation, with special regards to managers in the public sector. There is a potential that this paper can serve to justify how individual differences are able to weave their way among knowledge workers for performance improvement. The assessment of personality traits is performed using the Big Five Inventory, where the traits are extraversion, agreeableness, openness to experience, neuroticism and conscientiousness. Tacit knowledge sharing, on the other hand, is realized through mentoring and knowledge-sharing agenda. This current study is targeted at Malaysian public sector managers who are expected to distribute their valuable knowledge with others and help enhance individual productivity. Individual performance system is introduced as a measuring tool on individual productivity which comprises of four main components; knowledge and expertise, personal quality, leadership and community contribution. It is suggested that for the purpose of practising knowledge sharing, managers need to possess some personality traits to improve their employees' performance.
\end{abstract}

Keywords: tacit knowledge, knowledge sharing, personality traits, public sector

\section{Introduction}

Interest has been growing among public managers in exploring into the personality of their professional staff to ensure that their expertise is utilized with others. Personality traits thus, have assumed a very important role among the managers where they gradually begin to evaluate the characteristics of their subordinates a throughout various positions they hold in an organization. The development of this personality observation practice originated from a stream of studies in the early 1990s in which personality measures were shown to have a place in the management in terms of their validity and predictability; something that had not been proven in the past (Rothstein \& Goffin, 2006; Maccoby, 2009). Different personalities have their respective effects on how they perform at work (Judge, Bono, \& Locke, 2000) and this include his or her readiness in the aspect of knowledge-sharing. Knowledge-sharing activities and creating new knowledge have proven their significance in the construction of sustainable and competitive governments (Oliver \& Kandadi, 2006; Kan., Kim, \& Chang, 2008). To explain this, in the public sector, government officers who normally make the decisions or administrators need to decide more effectively and efficiently due to the public's rapidly changing demands and expectations, following the surge of globalization (Mokhtar, 2010). The government sector also has to answer to the growing demands made by the public and the increasing comparison and competition coming from the private sector.

Thus, the selection of appropriate personality has become integral, and knowledge distribution among the employees is urgently stressed as to create versatility in responses made to environmental changes. This signifies that the importance of the selection of individual characteristics such as agreeableness, conscientiousness and openness is irrefutable to influence knowledge sharing (Martzler, Renzi, Muller, Herting \& Mooradian, 2008) in the case of Malaysian public servants (Abdul Manaf, Armstrong \& Lawton, 2011). 
This paper makes a brief review over the suggestion made in current studies such as Martzler et al. (2008), Wang and Noe (2010) on the personality of the public managers, where they do not mind sharing tacit knowledge through mentoring and knowledge sharing mechanisms. In addition, the studies also review the important trends in research where the use of personality measures as predictors to job performance is measured. As we shall see, the implications of personality roles in knowledge-sharing practices towards individual performance in the Malaysian setting will be given particular attention.

\section{Background of the Study}

Rapid developments that have taken place across many sectors and the global demands that are constantly changing imply that government organizations can no longer keep on doing things the ways they have, just because the ways are thought to work well. As Osborne and Plastrik (2000) suggest in a catchy phrase, public organizations should be set to do the right things, instead of doing things right. In other words, there is a strong call for the steering functions that can help the organisations stay dynamic and obtain set targets, rather than focus on the rowing functions where they keep on performing things the same way (Osborne \& Plastrik, 2000).

Hence, some initiatives have been done for the creation and management of new knowledge, and the new knowledge has strategically found its place in the groundwork of public performance. A particular example would lie in the Malaysian aspiration in achieving vision 2020, a national project, with full-scale development expected out of the public sector performance. To meet the targets outlined in the $9^{\text {th }}$ Malaysia Plan, Malaysian administrators have established a number of strategies to increase government performance, particularly in the second term. One strategy includes introducing the concept of enhancing knowledge capabilities, being more creative and having the country equipped with 'first class human capital' (Government of Malaysia [GOM], 2008). It is believed that to be successful, one must have easy access to knowledge, and it must be feasible enough to derive benefit from the knowledge (Abdullah, 2005).

The knowledge, deemed vital for excellence performance in management can be tacit (Polanyi, 1966; Manaf et al., 2011; Rahimi, Seyyedi \& Damirchi, 2012). An organization is perceived as well-functioning and caters to the demands of its competitors if it has the capability of blending the knowledge, expertise and skills possessed by its employees; this also takes into account the amount of tacit knowledge that they have, that can be helpful in managerial practices (He \& Wei, 2009; Bennet \& Bennet, 2008).

The relevance of tacit knowledge in organizations cannot be denied. Employees tend to go out of balance in their time and workload, and this makes them have to rely on their common sense and intuition, or tacit knowledge in order to complete their tasks (Smith, 2001). The importance of having tacit knowledge is also stressed by a few statistical reports which show that 90 percent of organizational knowledge is embedded and synthesized in the minds of the employees (Wah, 1999). Therefore, organizations realize that tacit knowledge is of utmost importance when it comes to attracting and retaining talented, loyal and productive workforce (Smith, 2000). A great deal of such knowledge is weaved into social interactions via processes of communication and knowledge-sharing (Han \& Anantatmula, 2007; Rahimi et al., 2012).

On the other hand, individual characters can also determine their performance at work (Barrick \& Mount, 1991) and career success (Ng, Eby, Sorensen, \& Feldman, 2005). In public organizations, understanding personality is crucial for leaders to maintain the group's trust and loyalty. This understanding enables leaders to assign people into the roles which they think appropriate for them (Maccoby, 2009).

Hence, this paper is derived from the suggestion made by earlier studies, which is to encourage public servants to do the right things rather than doing things right. This is particularly important, since in the knowledge age, employees are expected to 'know-how' rather than 'know-what'. Despite having to try to meet those demands, the government sector also faces the challenge to keep its well-performing, efficacious staff before they retire or before they career mobility comes into the picture. This paper is concerned with the creation, application and the sharing of new knowledge that are actually important for building sustainable and competitive government (Kang et al., 2008; Willem \& Buelens, 2007; Osterloh \& Frey, 2000; Grant, 1996). However, this would not have been a success if individuals are not willing to share their knowledge.

The methodology in gathering information and insight for this paper includes library research and earlier proposal for empirical research that has been carried out. The writers has gathered evidences and information from both researches and secondary data derived from various sources.

\section{Notion of Knowledge}

Organizational knowledge on human workforce, as a concept, has been extensively discussed by relevant scholars like Polanyi (1966), Nonaka and Takeuchi, (1995), Cook and Brown, (1999), Miller and Morris, (1999), 
Leonard and Sensiper, (1998), Davenport and Prusak, (1998a), Ipe (2003) and Matthew and Sternberg (2009). Plato's interpretation of the concept of knowledge which is also adopted by most Western philosophers, is that knowledge is "justified true belief" (Small \& Sage, 2005). In 1945, Hayek highlighted knowledge as being important for the guidance and governance of society, although the importance of knowledge back then was still ambiguous (Hayek, 1945). The understanding of knowledge took a new turn in 1986 and 1990 when Romer explained the possible linkage between economics and knowledge. Knowledge is said to be the underlying factor that promotes performance, progress and economic growth, in local, national and even global domains (O. Romer, 1986; P. Romer, 1990). In 1969, Drucker took a look at the role of knowledge workers play in the modern knowledge economy and illustrated that knowledge is a meaningful economic resource in the knowledge society, more than capital or labour.

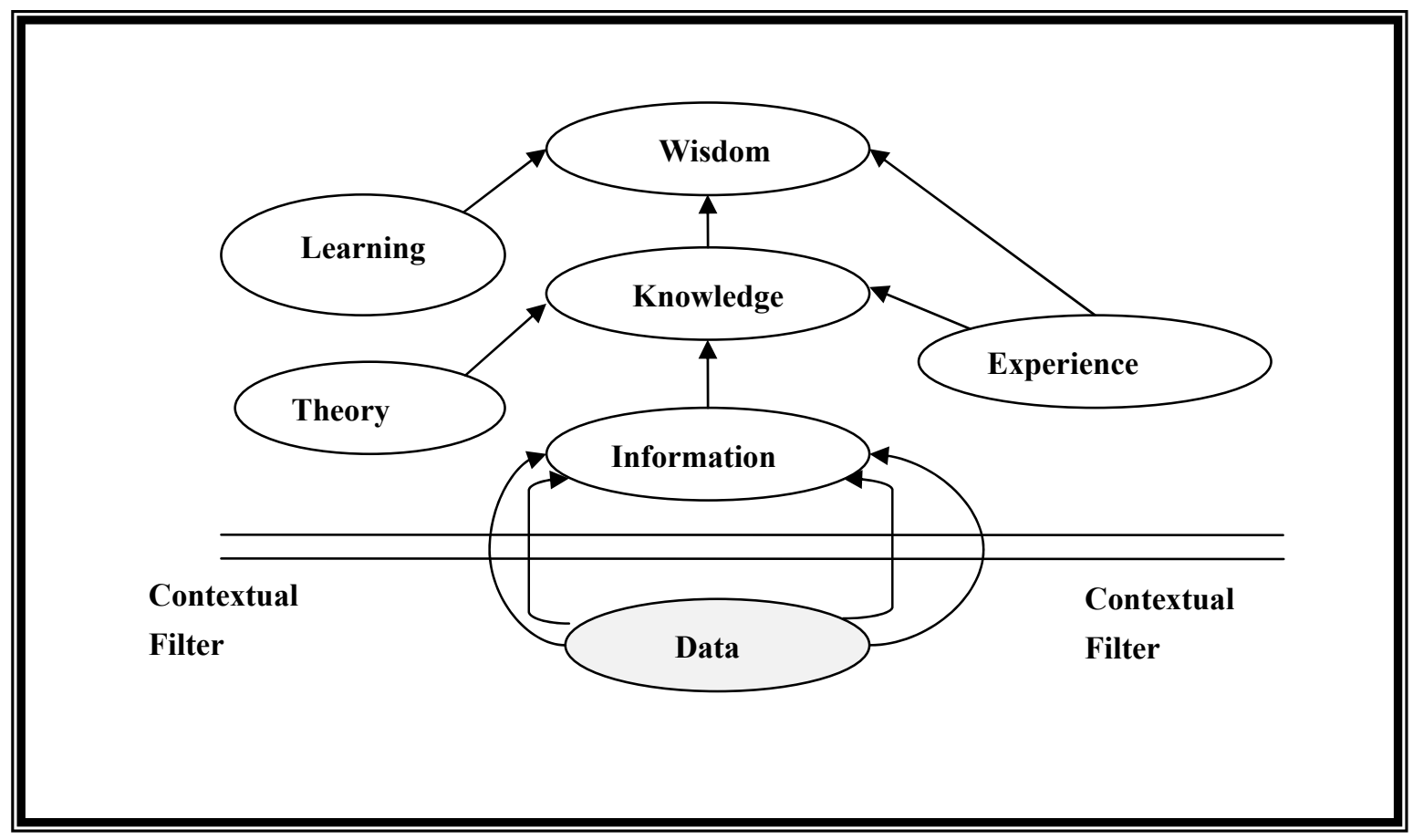

Figure 1. Knowledge: A derivative of theory, information, and experience

Source: Small and Sage, 2005: 154

As found in most knowledge-based studies, 'knowledge' is also established as data, information, knowledge and wisdom. The concept of knowledge is illustrated in Figure 1. At the most bottom level, knowledge is a body of data. Data are discrete facts which are compiled and presented objectively (Small \& Sage, 2005). The processing of data brings out information, a process which involves the arrangement, categorization and analysis of data and contexts. The context can encompass physical, virtual, mental elements, or the combination of any of the said elements. Therefore, knowledge is not called as such if it does not have information and a series of actions.

Davenport and Prusak (1998a) demonstrate that information is obtained from data and knowledge which originate from information. The highest level of understanding is represented by wisdom, one concept which refers to the ability to make use of knowledge the best way possible. It shows the ability to choose knowledge effectively and to apply appropriate knowledge in a certain situation (Davenport \& Prusak, 1998b).

Knowledge is a complicated thing and it comes in multiple forms. One clearest distinction has been made between tacit and explicit knowledge (Polanyi, 1966). This study defines tacit knowledge as knowledge that employees acquire from performing organizational work with success (Dixon, 2000). This knowledge involves knowing how to do the task assigned, plus the experiences and insights as contributory to individual and collective actions, thereby improving organizational performance (Ismail \& Sulong, 2013). In most situations, scholars discuss the issue of tacit knowledge together with other types of knowledge: namely explicit knowledge (Polanyi, 1966). Tacit knowledge is abstract but it does not hamper the identification of it as a type of knowledge. It stays embedded in mental processes, stemming from practical experiences, and expressed through applications and associated with a process of learning by acts of seeing and doing (Choi \& Lee, 2003). Meanwhile, explicit 
knowledge is very much codified and transmitted in a formal manner (Polanyi, 1966, Nonaka \& Takeuchi, 1998) translated into mediums such as manuals, mathematical expressions, copyright and various others (Smith, 2001). This knowledge can be created and transferred verbally or computerized, written down in patterns or diagrams and even created through technology (Choi \& Lee, 2003). Isaac (1999) claims that explicit knowledge is fixed, that it cannot turn to become tacit knowledge. However, the opposite would be able to work- meaning that tacit knowledge, in turn, can be converted to explicit knowledge.

\subsection{Knowledge Management in Public Sector}

Public organizations have aspired to achieve performance improvement via knowledge management agenda such as knowledge sharing and integration (Ruggles, 1998, Hasan \& Al-Hawari, 2003, Claycomb, Droge, \& Germain 2002). In particular, civil servants require profound insights and knowledge of how they can process demands made by the public as they have the responsibility to deal with the public a lot (Wiig, 2005). Since the private sector has come up with many knowledge management developments, people tend to anticipate the same things from the public sector. Consequently, government departments begin to take seriously the benefit of knowledge management implementation in improving its efficiency in decision-making and in the service delivery (Yao, Kam \& Chan, 2007; Skyrme, 2003).

A study by Syed Ikhsan and Rowland (2004) emphasises the fact that the availability of knowledge in government practices is evident through work procedures and policies, job manuals, ISO 9002, desk files, workflows and databases. It is also pointed out in the study that knowledge management activities via knowledge-sharing help improve employees' routine work. This leads to better service quality, better decision making, and better access to the latest information which go in tandem with customers' needs, all of which are influenced by knowledge-sharing.

\subsection{Knowledge Sharing in Public Sector}

The public sector promotes the culture of knowledge management to encourage knowledge-sharing among its organizational members, who believe that learning through sharing can well improve work performance (Gupta \& Govindarajan, 2000; Girdauskiene \& Savaneviciene, 2012), also organizational performance (Yao et al., 2007; Hsu, 2008; Wang \& Noe, 2010, Yang \& Maxwell, 2011; Dawes, Gharawi \& Burke, 2012). This is specifically addressed to the public sector because it is very much dependent on work-based knowledge and the implementation of knowledge sharing activities across departments (Willem \& Buelens, 2007). In recent years, the awareness of knowledge-sharing has been on the increase, together with the awareness that knowledge-sharing can address the facts that expertise is lacking and knowledge loss does exist in an organization (Wang \& Noe, 2010; Argote, McEvily \& Reagan, 2003).

Information-sharing stands out as the crux of knowledge management process in public administrations (Schmetz, 2002; Park \& Im, 2001). Although knowledge management has no longer been a novel issue among academics and practitioners, no one can deny the scarcity of information on knowledge management in public sector organisations in developing countries like Malaysia (Salleh \& Syed Ahmad, 2006).

Knowledge-sharing practices can be seen as a good social practice in government sectors, and civil servants have given warm responses to this initiative which they perceive as a way to contribute to the organizational mission. Overcoming the knowledge problem that arises due to staff turnover would be one clear example. If the staff has the readiness to exchange knowledge among them, then the existing employees will have the responsibility to disseminate work-related information to new employees. It is common that newcomers will build up their own foundation of knowledge of work from the group who initiates the knowledge-sharing (Al-Mashari \& Zairi, 2000; Chiem, 2001).

In this article, the aspect of individual tacit knowledge and personality in the organization in promoting knowledge-sharing will be emphasised. Knowledge-sharing refers to the acts of transferring, disseminating and acquiring knowledge, skills and ability among individuals. Generally, in an organization, one person will transfer work-related knowledge or expertise to others (Calantone, Cavusgil, \& Zhao, 2002; Kang et al., 2008). The knowledge-sharing process sees individuals in exchanging tacit and explicit knowledge, both of which later give birth to new knowledge (Hoof \& De Ridder, 2004; Holtshouse, 1998). However, the former, that emerges from the learning process is seen to have more value. It has been pointed out by fellow academicians that learning does not really take place unless an organization has an effective and efficient system of sharing and re-examining information (Moorman \& Miner, 1998). This refers strictly to tacit knowledge as this kind of knowledge is difficult to transfer and copy, since it is built through one's experiences and embedded as an individual skill (Liebeskind, 1996). 
The tacit knowledge sharing dimension is associated with the knowledge creation model, which is recommended by Nonaka \& Takeuchi (1995). There are five steps to the conversion of knowledge. Firstly, socialization denotes the process of sharing experiences that enables the creation of tacit knowledge such as shared mental models and technical skills (Nonaka \& Takeuchi, 1995). The socialization process allows tacit knowledge to be distributed through people instead of through impersonal media (Argote \& Ingram, 2000). Secondly, externalization is referred as a process of knowledge articulation, from tacit into explicit knowledge, normally through metaphors. Thirdly, combination involves activities that systemize concepts and manipulate knowledge by means of generating a knowledge system through different media. Meanwhile, internalization is a process of embodying explicit knowledge in tacit knowledge, for example, as in learning through practice (Nonaka \& Takeuchi, 1995). This conversion from tacit to explicit knowledge, also calls for new knowledge-sharing activities in the process.

As the government has expressed concern over the need to develop knowledge-sharing, various initiatives have been implemented to boost individuals' social interactions. Some instances are story-telling, coaching and meetings (Wiig, 2004, Bennet \& Bennet, 2008). Employees share their beliefs, thoughts, and experiences with others, thereby building a sound basis of common understanding (Yang, 2007). In the psychology and management literatures, it is suggested that mentoring relationships enable firms to share knowledge, encourage learning and build intellectual capital (Eddy, Tannenbaum, Lorenzet, \& Smith, 2005; Langkau \& Scandura, 2002, Sun, Aryee, \& Law, 2007). To make sure that knowledge sharing would be effective in the group, knowledge-sharing mechanisms (Boh, 2007) and mentoring programs (Eddy et al., 2005; Langkau \& Scandura, 2002) would be promoted as ways where ideas, experiences and skills can be exchanged among members.

\subsubsection{Mentoring Programs}

A mentor is an influential individual, has advanced experiences and knowledge, has the commitment to provide upward mobility and support to career (Ragins \& Scandura, 1999; Noe, 1988). Thus, mentoring programs open doors for senior employees in facilitating their junior employees establish a single dyadic relationship (Von Krogh, 1998; Higgins \& Kram, 2001). The mentoring programs can result in increased levels of career satisfaction and career success in terms of promotion, salaries and job performance for individuals (Aryee, Chay $\&$ Chew, 1996). On the other hand, at the organizational level, mentoring programs lend focus on cultural infrastructure and the supply of managerial talents (Aryee et al., 1996). Nonaka (1991) also stresses that mentoring programs can also be the right mechanism for sharing tacit knowledge. This study proposes mentoring programs to support the knowledge-sharing culture within organizations.

\subsubsection{Knowledge-Sharing Mechanism}

The knowledge-sharing mechanism is a procedure involved in the knowledge-sharing culture inculcated in an organization, which sheds light on the uses of information technology (IT) mechanisms and a personal mechanism approach (Chai, Gregory, \& Shi, 2003). Personal approaches also take into account apprenticeships and personnel transfer. A knowledge repository stands as a technological mechanism. Some studies categorize mentoring as formal and informal. The knowledge-sharing approach that is informal by nature, often takes place in uncalled for meetings, informal seminars or in a coffee room during chit-chats. Meanwhile, formal mechanisms manifest themselves in training sessions, formal procedures, rules, manuals and various others (Alavi \& Leidner, 2001; Bartol \& Srivastasa, 2002; Willem \& Buelens, 2007).

\subsection{Tacit Knowledge}

It has been acknowledged that tacit knowledge serves as both an outcome of experience-based learning and as a foundation crucial for continuous learning (Matthew \& Sternberg, 2009; Drysdale \& Mcbeath, 2012). Polanyi (1966) describes tacit knowledge as having the knowledge on how to do something without having to give it a thought. This type of knowledge is highly personal, subjective, informal and can be implicit (Sternberg, 1997). Simultaneously, some studies have broached on cognitive and technical dimensions. The former comprises of mental models, values, belief and perceptions. Meanwhile, the latter denotes a person's ability to have the proficiency in certain knowledge or skills (Smith, 2001, Nonaka 1991). In various companies, inexperienced managers employ technical tacit knowledge like diplomacy and human sense to deal with difficult employees effectively.

Sternberg suggests that tacit knowledge acquisition and use makes up what is termed as practical intelligence or a series of experiences. Practical intelligence puts this kind of knowledge as action-oriented, meaning that it enables an individual to reach goals that they personally value (Sternberg, 1990). People have resorted to various means like stories and analogies in giving their tacit knowledge to others (Stewart, 1997). In specific, this paper refers to managerial tacit knowledge as the abilities and skills of managers to organize themselves and others, and to distribute tasks. According to Wagner (1987), self-management includes possessing self-motivation and 
self-organization skills, where managing tasks address the question of how to perform successfully in certain tasks, whilst managing others is related to the knowledge of handling subordinates and interactions with colleagues.

\subsection{Personality Traits}

Personality is defined as a stable temperament, intellect and physique including having stable patterns of thoughts, emotions, and behaviour which extend to different situations through time (Eysenck, 1970; Costa \& Mc Crae, 1989; Funder, 2001). Fundamentally speaking, personality is examined based on five broad domains; neuroticism, extraversion, agreeableness, openness to experience or intellect, and conscientiousness. This five-factor model of personality (Goldberg, 1990; McCrae \& Costa, 1987; Cabrera, Collins, \& Salgado, 2006) has been used extensively in different fields like aviation (Grant, Marquis, Orre, Palinkas \& Suedfeld, 2007), politics (Schoen \& Schumann, 2007) and entrepreneurship (Zhao \& Seibert, 2006). As quoted from Cabrera et al (2006), individual characteristics are able to explain why some individuals have the motivation to pursue knowledge-sharing, compared to others. Personality traits are also found to determine job performance (e.g., Barrick \& Mount, 1991, Hurtz \& Donovan, 2000, Ones, Mount, Barrick, \& Hunter 1994). Research by Lowery, Beadles and Krilowicz (2004) indicates that there is a significant link between personality and performance, and to a certain degree, performance is dependent on a person's ability.

\section{The Role of Personality Traits and Sharing Tacit Knowledge on Performance}

Personality traits are instilled in individual characteristics and play important roles in promoting the sharing of valuable knowledge among themselves. For example, works by Martzler Renzi, Muller, Herting, and Mooradian, (2008), Cho, Li, and Su, (2007), Mooradian, Renzl, \& Matzler, (2006), Matzler and Muller, (2011) demonstrate that individual characteristics do have a role in knowledge sharing as mentioned in the earlier discussion. So far, knowledge-sharing has been predominantly studied in reference to the Big Five model that brings to the fore the five broad traits of human personality.

\subsection{Agreeableness}

'Agreeable' people are known to have some positive traits such as good-natured, forgiving, courteous, and cheerful (Barrick \& Mount, 1991). They have the tendency to help others so they learn more towards cooperating and collaborating rather than being competitive (Witt, Kaemar, Calrson \& Zinusnaka, 2000). There are parallel elements in the knowledge-sharing dimension such as collaboration (getting along well with others, career-wise), good interpersonal relationships with colleagues and supervisors (Martzler et al., 2008). An agreeable person may be willing to exchange knowledge with his or her recipients (De Vries, Den Hooff B. V. \& De Ridder, 2006). Being agreeable is a feature of trust that has a connection to the concept of knowledge-sharing (Abrams \& Cross, 2003). The affective and committed nature, also the knowledge acquisition of agreeable persons can influence knowledge sharing practices in the environment of the public sector. In this article, the affiliation between personality traits and knowledge-sharing practices is stressed, and the belief that the affiliation can be developed and associated with mentoring programs and knowledge-sharing mechanisms is expressed.

\subsection{Conscientiousness}

Conscientious individuals often demonstrate a sense of competence, reliability, responsible nature, good organization, hard work and self-discipline other than displaying his or her achievement-orientation (Barrick \& Mount, 1991). A relationship is said to exist between conscientiousness and performance (Matzler, Herting, \& Matzler, 2008; Mooradian et al., 2006); conscientiousness can enhance the performance that extends further than certain role requirements and which is rewarded contractually as job accomplishment (Organ \& Ryan, 1995). Practically, conscientiousness also determines learning orientation, which in turn influences knowledge-sharing (Matzler \& Muller, 2011). Learning-oriented individuals can never have problems in developing their abilities, promoting the idea of knowledge sharing to their fellow employees in order to achieve the objectives intended.

\subsection{Openness to Experiences}

Goldberg (1993) has classified one's openness to experiences as 'intellect'. This attitude shows a list of criteriaan active imagination, intellectual curiosity, originality to name a few (Costa \& McCrae, 1992). From five personality traits, the openness to experience has been shown to be the strongest predictor of knowledge sharing (Cabrera et al., 2006; Matzler et al., 2008; Matzler \& Muller, 2011). The person having this personality tends to share their knowledge regardless of what the outcome may be. The fact is these individuals with high levels of openness tend to be in pursuit of knowledge and share it in any way they can. 


\subsection{Extraversion}

Extraverts are people who cannot live without excitement and stimulation, and they are known to be 'bubbly', assertive, and optimistic among others (Costa \& McCrae, 1992). Managers of this type can be expected to engage themselves in more interactions with others and to become an active participant in the interactions. These interactions could promote the sharing of experiences that have been drawn from tacit knowledge. The findings by De Vries et al., (2006); Wang, Noe, \& Wang, (2011) suggest that extraverted people will be likely to have a positive influence on knowledge sharing. There is a possibility that there is a link between extraversion and the stress in gaining status (Barrick, Parks, \& Mount, 2005), identified as a motivating factor for knowledge-sharing (Ardichvili, 2008).

\subsection{Neuroticism}

Neuroticism relates to the psychological adjustment and the lack of emotional stability. The characteristics of neurotic people can easily be seen in their traits such as anxiety, depression and others (Costa \& McCrae, 1992). Highly neurotic people have experienced multiple issues that are linked with a number of negative moods (Judge, Thoresan, \& Barrick, 1999). People in neurotic state have the likelihood to be impacted by negative life events and are usually in a bad mood (Suls, Green \& Hillis 1998). A study by Wang and Yang, (2007) has validated the fact that there is non-existent significant relationship between neuroticism and knowledge-sharing intention.

\section{Individual Performance Appraisal in the Malaysian Government}

Performance appraisals have been seen to be in favour of the appraisal process due to several factors: 1) it offers managers a good communication tool for employees' goal setting and performance planning, 2) it improves employees' degree of motivation and productivity, 3) it helps in the discussions with regards to employees' growth and development, 4) it provides a concrete foundation for wage and salary administration and 5) it supplies a body of data for various human resource decisions (Longenecker \& Nykodym, 1996). We have every reason to believe that public agencies might be able to enhance their performance through a lot of individual characteristics and multifarious activities that concern with knowledge acquisition (Hall, 2007).

Malaysia has implemented its individual performance appraisals for public servants in light of 4 main components namely, (1) knowledge and expert (50\%), (2) personal quality (30\%), (3) leadership (15\%) and (4) community contribution (5\%) (Public Service Department Malaysia [PSDM], 2009). From such an evaluation, $30 \%$ is reserved for personal quality where it is primarily associated with individual personality. Thus, personality stands out as the second largest component that has been appraised by the government as its initiative to detect the right person capable to work in certain positions. Put simply, there is a hint that the government believes that public servants have various personalities which in turn, can be exercised to the best of their advantage to hold different work positions.

It is also crucial to note that the government has provided $50 \%$ weight on individual knowledge and skills. This is harmonious with the government's aim to add up more knowledgeable and talented workers to constitute quality government staff. The above allocations have suggested that the government has not taken lightly the act of monitoring the knowledge and personality aspects of its public servants. The importance of these two aspects in evaluating individual performance has also been properly documented. Therefore, this paper carries a suggestion that public servants should share their expertise on managerial tacit knowledge with other members of the organizations. Perhaps, personality traits that have been discussed above are useful enough to identify specific traits of managers who do not mind sharing their knowledge.

\section{Conclusions}

To summarize, to increase government performance particularly in the Malaysian government setting, it is suggested that the specific traits of personality and mechanism of sharing tacit knowledge can well be considered for individual performance. As has been discussed, it is widely accepted that the impact of personality and sharing tacit knowledge on job performance has been a great one. Thus, to make use of the knowledge through sharing tacit knowledge in the government sector, managers should learn to understand individual personality because their subordinates have varying characteristics and behaviours which should be manipulated to the best of their advantage, and in turn would benefit the organization in general.

\section{References}

Abdul Manaf, H., Armstrong, S. J., \& Lawton, A. (2011). Knowledge sharing practices, managerial tacit knowledge, and individual performance: Their interrelationships and the moderating role of employee personality. European Conference on Knowledge Management, Passau, Germany. 
Abdullah, A. B. (2005, July 7th), Speech at the International Conference On Knowledge Management. Kuala Lumpur, Malaysia: Putra World Trade Centre.

Abrams, L., C., \& Cross, R. (2003). Nurturing interpersonal trust in knowledge sharing networks. Academy of Management Executives, 17(4), 64-77. $\quad$ Retrieved from https://www.google.com.my/\#hl=en\&tbo=d\&sclient=psy-ab\&q=Nurturing+interpersonal + trust + in + knowle dge + sharing + networks\&oq $=$ Nurturing + interpersonal + trust + in + knowledge + sharing + networks\&gs_l $1=$ serp. 3 . .0i30.3265.3265.0.4500.1.1.0.0.0.0.188.188.0j1.1.0.les\%3B http://dx.doi.org/10.5465/AME.2003.11851845

Alavi, M., \& Leidner, D. E. (2001). Review: Knowledge management and knowledge management system: conceptual foundations and research issues. MIS Quarterly, 24(1), 107-136. http://dx.doi.org/10.2307/3250961

Al-Mashari, M., \& Zairi, M. A. (2000). Revisiting BPR: A holistic review of practice and development. Business Process Management Journal, 6(1), 10-42. http://dx.doi.org/10.1108/14637150010283045

Ardichvili, A. (2008). Learning and knowledge sharing in virtual communities of practice: Motivators, barriers, and enablers. Advances in Developing Human Resources, 10(4), 541-554. http://adh.sagepub.com/content/10/4/541 http://dx.doi.org/10.1177/1523422308319536

Argote, L., \& Ingram, P. (2000). Knowledge transfer: A basis for competitive advantage in firms. Organizational Behaviour and Human Decision Process, 82(1), 150-169. http://dx.doi.org/10.1006/obhd.2000.2893

Argote, L., McEvily, B., \& Reagan, R. (2003). Introduction to the special issue on managing knowledge in organization: creating, retaining and transferring knowledge. Management Sciences, 49(4), 5-8. http://dx.doi.org/10.1287/mnsc.49.4.0.14421

Aryee, S., Chay, Y., W., \& Chew, J. (1996). The motivation to mentor among managerial employees and integrationist approach. Group \& Organizational Studies, 21(3), 261-277. http://dx.doi.org/10.1177/1059601196213002

Barrick, M. R., \& Mount, M. K. (1991). The big five personality dimensions and job performance: A meta analysis. Personnel Psychology, 44, 1-26. http://dx.doi.org/10.1111/j.1744-6570.1991.tb00688.x

Barrick, M., R., Parks, L., \& Mount, M., K. (2005). Self monitoring as a moderator of the relationship between $\begin{array}{lllll}\text { personality traits and performance. Personnel Psychology, 58, } & \text { 745-767. }\end{array}$ http://dx.doi.org/10.1111/j.1744-6570.2005.00716.x

Bartol, K. M., \& Srivastava, A. (2002). Encouraging knowledge sharing: The roles of organizational reward $\begin{array}{lllll}\text { system. Journal of Leadership and Organizational Studies, 9(1), } & \text { 64-77. }\end{array}$ http://dx.doi.org/10.1177/107179190200900105

Bennet, D., \& Bennet, A. (2008). Engaging tacit knowledge in support of organizational learning. The Journal of Information and Knowledge Management System, 38(1), 72-94.

Boh, W. F. (2007). Mechanisms for sharing knowledge in project-based organizations. Information and Organization, 17, 27-58. http://dx.doi.org/10.1016/j.infoandorg.2006.10.001

Cabrera, A., Collins, W. C., \& Selgado, J. F. (2006). Determinants of individual engagement in knowledge sharing. International Journal of Human Resources Management, 17(2), 245-264. http://dx.doi.org/10.1080/09585190500404614

Calantone, R. J., Cavusgil, S. T., \& Zhao, Y. (2002). Learning orientation, firm innovation capability and firm $\begin{array}{llll}\text { performance. Industrial Marketing } & \text { Management, } & 31,\end{array}$ http://dx.doi.org/10.1016/S0019-8501(01)00203-6

Chai, K., Gregory, M., \& Shi, Y. (2003). Bridging island of knowledge: A framework of knowledge sharing mechanism. International Journal of Technology Management, 25(8), 703-727. http://dx.doi.org/10.1504/IJTM.2003.003133

Chiem, P. X. (2001, August). In the public interest: government employees also need incentives to share what they know. KM Magazine.

Cho, N., Li, G. Z., \& Su, C. (2007). An empirical study on the effect of individual factors on knowledge sharing by knowledge type. Journal of Global Business and Technology, 3(2), 1-15.

Choi, B., \& Lee, H. (2003). An empirical investigation of KM styles and their effect on corporate performance. Information and Management, 40(5), 403-417. http://dx.doi.org/10.1016/S0378-7206(02)00060-5 
Claycomb, C., Droge, C., \& Germain, R. (2002). Applied product quality knowledge and performance. International Journal of Quality \& Reliability Management, 19(6), 649-671. http://dx.doi.org/10.1108/02656710210429555

Cook, S., D., \& Brown, J., S. (1999). Bridging epistemologies: The generative dance between organizational knowledge and organizational knowing. Organizational Sciences, 10(4), 381-400. http://dx.doi.org/10.1287/orsc.10.4.381

Costa, J. R., \& McCrae, R. R. (1989). NEO PI-R professional manual. Odessa, F1: Psychological Assessment Resources, Inc.

Costa, J. R., \& McCrae, R. R. (1992). Professional manual revised NEO personality inventory (NEO PI-R) and NEO five factor inventory. Odessa, F1: Psychological Assessment Resources, Inc.

Davenport T. H., \& Prusak, L. (1998a). Working knowledge: How organization manage what they know. Boston: Harvard Business School Press.

Davenport, T. H., \& Prusak, L. (1998b). KM in business world. Rota Press.

Dawes, S. S., Gharawi, M. A., \& Burke, G. A. (2012). Transnational public sector knowledge networks: Knowledge and information sharing in a multi-dimensional context. Government Information Quarterly, 29(1), 112-120. http://dx.doi.org/10.1016/j.giq.2011.08.002

De Vries, R. E., Den Hooff, B. V., \& De Ridder, J. A. (2006). Explaining knowledge sharing: The role of team communication styles, job satisfaction and performance beliefs. Communication Research, 33(2), 115-135. http://dx.doi.org/10.1177/0093650205285366

Dixon, N. M. (2000). Common knowledge: How company thrive by sharing what they know. Boston: Harvard Business School Press.

Drucker, P. F. (1969). The age of discontinuity: Guidelines to our changing society. New York: Harper \& Row.

Drysdale, M. T. B., \& McBeath, M. (2012). Self-concept and tacit knowledge: Differences between cooperative and non-cooperative education students. Asia-Pacific Journal of Cooperative Education, 13(3), 169-180.

Eddy, E. R., Tannenbaum, S. I., Lorenzet, S. J., \& Smith-Jentsch, K. A. (2005). The influences of a continuous learning environment on peer mentoring behaviour. Journal of Managerial Issues, 17(3), 383-395.

Eysenck, H. J. (1970). The structure of human personality (3rd ed.). London: Methuen.

Funder, D. C. (2001). The personality puzzle (2nd ed.). New York: Norton.

Girdauskiene, L., \& Savaneviciene, A. (2012). Leadership role implementing knowledge transfer in creative organization: how does it work? Social and Behavioral Sciences, 41, 15-22.

Goldberg, L. R. (1990). An alternative description of personality-the big five factor structure. Journal of Personality and Social Psychology, 59(6), 1216-1229. http://dx.doi.org/10.1037/0022-3514.59.6.1216

Government of Malaysia. (2008). Ninth Malaysia Plan 2006-2010. Putrajaya, Malaysia: Government of Malaysia.

Grant, I., Erksen, H. R., Marquis, P., Orre, I. J., Palinkas, L. A., \& Suedfeld, P. (2007). Psychological selection of Antarctic personnel: The "SOAP" instrument. Aviation Space and Environment Medicine, 78(8), 793-800.

Grant, R. M. (1996). Towards a knowledge based theory of the firm. Strategic Management Journal, 17, $109-122$.

Gupta, A. K., \& Govindarajan, V. (2000). Knowledge flows within multinational corporations. Strategic $\begin{array}{lll}\text { Management Journal, } & \text { 473-496. }\end{array}$ http://dx.doi.org/10.1002/(SICI)1097-0266(200004)21:4<473::AID-SMJ84>3.0.CO;2-I

Hall, J. L. (2007). Implication of success and persistence for public sector performance. Public Organization Review, 7, 281-297. http://dx.doi.org/10.1007/s11115-007-0037-0

Han, B. M., \& Anantatmula, V. S. (2007). Knowledge sharing in large IT organizations: A case study. The Journal of Information and Knowledge Management System, 37(4), 421-439.

Hasan, H., \& Al-Hawari, M. (2003). Managing style and performance: A knowledge space framework. Journal of Knowledge Management, 7(4), 92-105. http://dx.doi.org/10.1108/13673270310492912

Hayek, F. A. (1945). The use of knowledge in society. American Economic Review, 25(4), 519-530. 
He, W., \& Wei, K. (2009). What drives continued knowledge sharing? An investigation of knowledge-contribution and seeking beliefs. Decision Support System, 46, 826-838. http://dx.doi.org/10.1016/j.dss.2008.11.007

Higgins, M. C., \& Kram, K. E. (2001). Reconceptualizing mentoring at work: A development network perspective. Academy of Management Review, 26(2), 264-288.

Holtshouse, D. (1998). Knowledge research issues, in special issues on knowledge and the firm. California Management Review, 40(3), 277-280. http://dx.doi.org/10.2307/41165955

Hooff, B. V., \& De Ridder, J. A. (2004). KS in context: The influence of organization commitment, communication climate and CMC use on knowledge sharing. Journal of Knowledge Management, 8(6), 117-130. http://dx.doi.org/10.1108/13673270410567675

Hsu, I. C. (2008). Knowledge sharing practices as a facilitating factor for improving organizational performance through human capital: a preliminary test. Expert Systems with Applications, 35(3), 1316-1326. http://dx.doi.org/10.1016/j.eswa.2007.08.012

Hurtz, G. M., \& Donovan, J. J. (2000). Personality and job performance: The Big Five revisited. Journal of Applied Psychology, 85(6), 869-879. http://dx.doi.org/10.1037/0021-9010.85.6.869

Ipe, M. (2003). Knowledge sharing in organization: A conceptual framework. Human Resources Development Review, 2(4), 337-359. http://dx.doi.org/10.1177/1534484303257985

Isaac, W. (1999). Dialog and the art of thinking together. New York: Currency/Doubleday.

Ismail, R. D. R., \& Sulong, Z. (2013). Knowledge management: A case study on employees knowledge-oriented behaviour in the electricity distribution company. Asian Social Science, 9(7), 218-230. http://dx.doi.org/10.5539/ass.v9n7p218

Judge, T. A., Bono, J. E., \& Locke, E. A. (2000). Personality and job satisfaction: The mediating role of job $\begin{array}{lllll}\text { characteristics. Journal of } & \text { Applied }\end{array}$ http://dx.doi.org/10.1037/0021-9010.85.2.237

Judge, T. A., Higgins, C. A., Thoresan, C. J., \& Barrick, M. R. (1999). The big five personality traits, general mental ability and career success across the life span, Personnel Psychology, 52, 621-651. http://dx.doi.org/10.1111/j.1744-6570.1999.tb00174.x

Kang, Y., Kim, S., \& Chang, G. (2008). The impact of knowledge sharing on work performance: An empirical analysis of the public employees' perceptions in South Korea. International Journal of Public Administration, 31, 1548-1568. http://dx.doi.org/10.1080/01900690802243607

Langkau, M. J., \& Scandura, T. A. (2002). An investigation of personal learning in mentoring relationship: content, antecedents and consequences. Academy of Management Journal, 45, 779-790. http://dx.doi.org/10.2307/3069311

Leonard, D., \& Sensiper, S. (1998). The role of tacit knowledge in group innovation. California Management Review, 40(3), 112-132. http://dx.doi.org/10.2307/41165946

Liebeskind, J. P. (1996). Knowledge, strategy and the theory of the firm. Strategic Management Journal, 17, 93-107.

Longenecker, C. O., \& Nykondym, N. (1996). Public sector performance appraisal effectiveness: A case study. Public Personnel Management, 25(2), 151-164.

Lowery, C. M., Beadles, N. A., \& Krilowicz, T. J. (2004). Using personality and cognitive ability to predict job performance: An empirical study. International Journal of Management, 21(3), 300-306.

Maccoby, M. (2009, Jan/Feb). To win the respect of followers, leaders need personality intelligence. Ivey Business Journal.

Martzler, K., Renzi, B., Muller, J., Herting, S., \& Mooradian, T. A. (2008). Personality traits and knowledge sharing. Journal of Economic Psychology, 29(3), 301-313. http://dx.doi.org/10.1016/j.joep.2007.06.004

Matthew, C. T., \& Sternberg, R. J. (2009). Developing experience-based (tacit) knowledge through reflection. Learning and Individual Differences, 19, 530-540. http://dx.doi.org/10.1016/j.lindif.2009.07.001

Matzler, K., \& Mueller, J. (2011). Antecedents of knowledge sharing - Examining the influence of learning and performance orientation. Journal of Economic Psychology, 32(3), 317-329. Retrieved from $\mathrm{http}: / /$ www.sciencedirect.com/science/article/pii/S0167487010001406 
http://dx.doi.org/10.1016/j.joep.2010.12.006

McCrae, R. R., \& Costa, P. T. (1987). Validation of five-factor model of personality across instruments and observers. Journal of Personality and Social Psychology, 82(1), 112-127.

Miller, W. L., \& Morris, L. (1999). Fourth generation R\&D: Managing knowledge, technology and innovation. New Jersey Wiley: Hoboken.

Mokhtar, I. A. (2010). Formal and informal learning opportunities in government organizations: Experiences of public sector employees from six asian nations. Australian Journal of Adult Learning, 50(2), 387-480.

Mooradian, T., Renzl, B., \& Matzler, K. (2006). Who trust? Personality, trust and knowledge sharing. Management Learning, 37(4), 523-540. http://dx.doi.org/10.1177/1350507606073424

Moorman, C., \& Miner, A. S. (1998). Organizational improvisation and organizational memory. Academy Management Review, 23(4), 698-723.

Ng, T. W. H., Eby, L. T., Sorensen, K. L., \& Feldman, D. C. (2005). Predictors of objective and subjective career $\begin{array}{llllll}\text { success: } & \text { A meta-analysis. Personnel }\end{array}$ http://dx.doi.org/10.1111/j.1744-6570.2005.00515.x

Noe, R. A. (1988). An investigation of the determinants of successfully assigned mentoring relationships. Personnel Psychology, 41, 457-479. http://dx.doi.org/10.1111/j.1744-6570.1988.tb00638.x

Nonaka, H., \& Takeuchi. (1995). The knowledge creating company. New York: Oxford University Press.

Nonaka, I. (1991). The knowledge-creating company. Harvard Business Review, Nov-Dec.

Nonaka, I., \& Konno, N. (1998). The concept of 'Ba': Building a foundation for knowledge creation. California Management Review, 40(3), 40-54. http://dx.doi.org/10.2307/41165942

Oliver, S., \& Kandadi, K. R. (2006). How to develop knowledge culture in organizations? A multiple case study of large distributed organization. Journal of Knowledge Management, 10(4), 6-24. http://dx.doi.org/10.1108/13673270610679336

Ones, D. S., Mount, M. K., Barrick, M. R., \& Hunter, J. E. (1994). Personality and job performance: A critique of the Tett.

Organ, D. W., \& Ryan, M. (1995). A meta-analytic review of attitudinal and dispositional predictors of

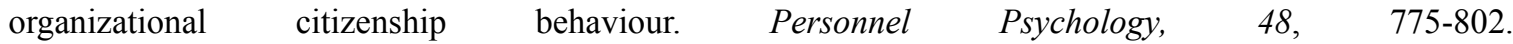
http://dx.doi.org/10.1111/j.1744-6570.1995.tb01781.x

Osborne, D., \& Plastrik, P. (2000). The reinventors' fieldbook: Tools for transforming your government. San Francissco, CA: Jossey Bass.

Osterloh, M., \& Frey, B. S. (2000). Motivation, knowledge transfer and organizational forms. Organizational Sciences, 11(5), 538-550. http://dx.doi.org/10.1287/orsc.11.5.538.15204

Park, H. S., \& Im, B. C. (2001). Test of causal model for the efficient of the servants knowledge in the local administration. Korean Policy Studies Review, 10(1), 111-135.

Polanyi, M. (1966). The tacit dimension. New York: Doubleday.

Public Service Department Malaysia. (2009). Performance appraisals Malaysian government officers. Government of Malaysia:Service Secular number 2.

Ragins, B. R., \& Scandura, T. A. (1999). Burden or blessing? Expected costs and benefits of being a mentor. Journal of Organizational Behavior, 493-509. http://dx.doi.org/10.1002/(SICI)1099-1379(199907)20:4<493::AID-JOB894>3.0.CO;2-T

Rahimi G., Seyyedi, M. H., \& Damirchi, Q. Z. (2012). The role of tacit knowledge in innovation of public management. 2012 International Conference on Education and Management Innovation [IPEDR], 30, $292-296$.

Romer, O. (1986). Increasing returns and long run growth. Journal of Political Economy, 94(5), 1002-1037. http://dx.doi.org/10.1086/261420

Romer, P. (1990). Endogenous technological change. Journal of Political Economy, 98(5), 71-102. http://dx.doi.org/10.1086/261725

Rothstein, M. G., \& Goffin, R., D., (2006). The use of personality measures in personnel selection: What does current research support? Human Resource Management Review, 16, 155-180. 
http://dx.doi.org/10.1016/j.hrmr.2006.03.004

Ruggles, R. (1998). The state of the notion: Knowledge management in practice. California Management Review, 40(3), 80-89. http://dx.doi.org/10.2307/41165944

Salleh, K., \& Syed Ahmad, S. N. (2006). KM strategy for E-Government: An exploratory study of Local Authorities in Malaysia. International Conferences on eGovernance enhancement Via Knowledge Management, Malaysia, Kuala Lumpur.

Schmetz, F. (2002). Introduction to KM in the public sector. In L. J. Yao, T. H. Y. Kam, \& S. H. Chan (2007), Knowledge sharing in Asian public administration sector: The case of Hong Kong, Journal of Enterprise Information Management, 20(1), 51-69.

Schoen, H., \& Schumann, S. (2007). Personality traits, partisan attitudes and voting behaviour, evidence from Germany. Political Psychology, 28(4), 471-498. http://dx.doi.org/10.1111/j.1467-9221.2007.00582.x

Skyrme, D. J. (2003, December 11). The 3Cs of knowledge sharing: Culture, competition and commitment. Ark Group/David Skyrme Associates. Retrieved from http://skyrme.com/updates/u64-f1.htm

Small, C. T., \& Sage, A. P. (2005). Knowledge management and knowledge sharing: A review. Information Knowledge Systems Management, 5, 153-169

Smith, E. A. (2000). Applying knowledge enabling methods in the classroom and workplaces. Journal of Workplace Learning, 5(4), 311-321.

Smith, E. A. (2001). The roles of tacit and explicit knowledge in the workplace. Journal of Workplace Learning, 12(6), 236-244. http://dx.doi.org/10.1108/13665620010343505

Sternberg, R. J. (1990). Wisdom and its relation to intelligence and creativity. In R. J. Sternberg (Ed.), Wisdom: Its nature, origin and development (pp. 142-159). New York: Cambridge University Press. http://dx.doi.org/10.1017/CBO9781139173704.008

Sternberg, R. J. (1997). Successful intelligence. New York: Penguin Putnam.

Stewart, T. A. (1997). Intellectual capital. New York: Doubleday.

Suls, J., Green, P., \& Hillis, S. (1998). Emotional reactivity to everyday problems, affective inertia and neuroticism. Personality and Social Psychology Bulletin, 24, 127-136. http://dx.doi.org/10.1177/0146167298242002

Sun, L., Aryee, S., \& Law, K. S. (2007). High performance human resource practices, citizenship behaviour and organizational performance: A relational perspective. Academy of Management Journal, 50(3), 558-577. http://dx.doi.org/10.5465/AMJ.2007.25525821

Syed Ikhsan, S. O. S., \& Rowland, F. (2004). Benchmarking knowledge management in a public organization in Malaysia. Benchmarking: An International Journal, 11(3), 238-266. http://dx.doi.org/10.1108/14635770410538745

Von Krogh, G. (1998). Care in knowledge creation. California Management Review, 40(3), 133-153. http://dx.doi.org/10.2307/41165947

Wagner, R. K. (1987). Tacit knowledge in everyday intelligence behaviour. Journal of Personality and Social Psychology, 1(4), 301-312.

Wah, L. (1999, April). Behind the buzz. Management Review, 17-26.

Wang, \& Noe, R. A. (2010). Knowledge sharing: A review and directions for future research. Human Resource Management Review, 20(2), 115-131. http://dx.doi.org/10.1016/j.hrmr.2009.10.001

Wang, C. C., \& Yang, Y. J. (2007). Personality and intention to share knowledge: An empirical study of scientists in an R\&D laboratory. Social Behavior and Personality: An International Journal, 35(10), 1427-1436. Retrieved from http://www.ingentaconnect.com/content/sbp/sbp/2007/00000035/00000010/art00015

Wang, S., \& Noe, R. A. (2010). Knowledge sharing: A review and directions for future research. Human Resource Management Review, 20(2), 115-131. http://dx.doi.org/10.1016/j.hrmr.2009.10.001

Wang, S., Noe, R. A., \& Wang, Z. M. (2011). Motivating knowledge sharing in knowledge management systems: A quasi-field experiment. Journal of Management, 37(4). Retrieved from http://jom.sagepub.com/content/early/2011

Wiig, K. (2004). People focused knowledge management. Oxford: Elsevier. 
Wiig, K. M. (2005). Application of knowledge management in public administration. Paper to Public Administration of the City of Taipei, Taiwan.

Willem, A., \& Buelens, M. (2007). Knowledge sharing in public sector organizations: The effect of organizational characteristics on Interdepartmental knowledge sharing. Journal of Public Administration Research and Theory, 17(4), 581-606. http://dx.doi.org/10.1093/jopart/mul021

Witt, L. A., Kaemar, K. M., Calrson, D. S., \& Zinusnaka. (2000). Interactive effects on personality and organizational politic on contextual performance. Journal of Organizational Behaviour, 23(8), 911-926. http://dx.doi.org/10.1002/job.172

Yang, J. (2007). The impact of knowledge sharing on organizational learning and effectiveness. Journal of Knowledge Management, 11(2), 83-90. http://dx.doi.org/10.1108/13673270710738933

Yang, T., \& Maxwell, T. A. (2011). Information-sharing in public organizations: A literature review of interpersonal, intra-organizational and inter-organizational success factors. Government Information Quarterly, 28(2), 164-175. http://dx.doi.org/10.1016/j.giq.2010.06.008

Yao, L. J., Kam, T. H. Y., \& Chan, S. H. (2007). Knowledge sharing in Asian public administration sector: The case of Hong Kong. Journal of Enterprise Information Management, 20(1), 51-69. http://dx.doi.org/10.1108/17410390710717138

Zhao, H., \& Seibert, S. E. (2006). The big five personality dimensions and entrepreneurial status: A meta analysis review. Journal of Applied Psychology, 91(2), 259-271. http://dx.doi.org/10.1037/0021-9010.91.2.259

\section{Copyrights}

Copyright for this article is retained by the author(s), with first publication rights granted to the journal.

This is an open-access article distributed under the terms and conditions of the Creative Commons Attribution license (http://creativecommons.org/licenses/by/3.0/). 